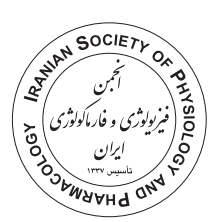

\title{
Antioxidant activity, phenolic and flavonoid content of Lawsonia inermis and Haplophyllum vermiculare
}

Alireza Moulazadeh ${ }^{1}$, Seyyed Amin kouhpayeh ${ }^{1,2}$, Razieh Ranjbar ${ }^{1}$, Amin Dakhili Ardestani ${ }^{3}$, Maryam Hekmat ${ }^{3}$, Sara Azarnia ${ }^{1}$, Sohrab Najafipour ${ }^{2,4^{*}}$ (D)

1. Noncommunicable Disease Research Center, Fasa University of Medical Sciences, Fasa, Iran

2. Medicinal Plant Research Center, Fasa University of Medical Sciences, Fasa, Iran

3. Student Research Committee, Fasa University of Medical Sciences, Fasa, Iran

4. Department of Microbiology, Fasa University of Medical Sciences, Fasa, Iran

\section{ABSTRACT}

Introduction: Continuous exposure of oxidants to the skin may disrupt the antioxidant balance and leads to inflammatory skin diseases (ISD). The aim of the present study was to compare the antioxidant activity, phenolic and flavonoid content of two traditionally used plants in ISD, Lawsonia inermis and Haplophyllum vermiculare.

Methods: The hydroethanolic extract of the plants was prepared by maceration. Phenolic and flavonoid content of the extracts was measured respectively with Folin-Ciocateu and aluminum chloride methods. The monovalent reducing power and radical scavenging activity were also evaluated respectively by ferric reducing antioxidant power and 2,2-diphenyl-1picryl-hydrazyl methods.

Results: The reducing power of Lawsonia inermis $\left(862.89 \pm 32.23 \mu \mathrm{molFe}^{2+} / \mathrm{g}\right)$ was significantly higher than Haplophyllum vermiculare extract $\left(765.52 \pm 29.39 \mu \mathrm{molFe}{ }^{2+} / \mathrm{g}\right)$. The radical scavenging activity of Lawsonia inermis extract at a concentration of $1000 \mu \mathrm{g} / \mathrm{ml}$ $(\% 65.72 \pm 0.77)$ was also significantly higher than Haplophyllum vermiculare $(\% 36.34 \pm 2.52)$. The higher antioxidant activity of Lawsonia inermis is probably due to its higher phenolic (96.76 $\pm 3.34 \mu \mathrm{g} \mathrm{GAE} / \mathrm{mg})$ and flavonoid content (197.69 $\pm 5.76 \mu \mathrm{g} \mathrm{QE} / \mathrm{mg})$.

Conclusion: Henna leaves had higher antioxidant activity, phenolic and flavonoid content compared to aerial parts of Haplophyllum vermiculare, and may be more effective in improving oxidative stress, prevention and treatment of ISD.

\author{
Keywords: \\ Lawsonia inermis \\ Haplophyllum vermiculare \\ Antioxidative activity \\ Skin disease \\ Inflammation
}

\section{Introduction}

Skin is one of the innate immunity mechanisms that prevents the entry of germs and harmful substances into the body. Skin exposes to a variety of chemical and physical stimuli, such as reactive oxygen species (ROS) produced by immune cells or enzymatic activities and environmental stimuli (UV light and pollutants) (Shah and Sinha 2013). Prolonged exposure to oxygen and other damaging agents make the skin particularly susceptible to oxidative stress (Kalkan et al., 2014). Oxidative stress is a condition in which ROS and other oxidants overcome the antioxidant system and disrupt

\footnotetext{
* Corresponding author: Sohrab Najafipour, Najafipour.s@fums.ac.ir

Received 17 June 2020; Revised from 9 September 2020; Accepted 11 December 2020
}

Citation: Moulazadeh A, kouhpayeh S.A, Ranjbar R, Dakhili Ardestani A, Hekmat M, Azarnia S, Najafipour S. Antioxidant activity, phenolic and flavonoid content of Lawsonia inermis and Haplophyllum vermiculare. Physiology and Pharmacology 2021; 25: 261-269. http://dx.doi.org/10.52547/ppj.25.3.261 
cellular and tissue homeostasis. Changes in homeostasis lead to the development of various inflammatory skin diseases (ISD) such as psoriasis, contact dermatitis, atopic dermatitis and urticaria (Sies, 2015). Therefore, improving the antioxidant system seems to be very effective in treatment of ISD.

Lawsonia inermis, popularly known as henna, is a perennial tree of the Lythraceae family that grows in arid and warm areas. In traditional Iranian medicine, this herb is widely used on the skin because of its pleasant smell and color. The orange color of henna is derived from a compound called lawsone (2-hydroxy-1,4napthoquinone), which makes up about $2 \%$ of its leaf (Mastanaiah et al., 2011). The phytochemical analysis of Lawsonia inermis has indicated the presence of more than a hundred bioactive molecules like phenolic acids, flavonoids, coumarins, triterpenoids, naphthalene derivatives, organic acids, quinoids and xanthones (AlSnafi 2019).

Haplophyllum vermiculare is another herb that is especially used in rural areas of Fars province, Iran to reduce skin inflammation. The most common use of Haplophyllum vermiculare is skin inflammation following snake and scorpion stings. Haplophyllum vermiculare is a shrubby plant of the Rutaceae family and usually its aerial parts are cut off and put on the skin as a poultice in ISD. The phytochemical analysis of Lawsonia inermis has indicated the presence of alkaloids, lignans, coumarins, flavanoids, essential oil and volatile oil in the aerial parts of Haplophyllum vermiculare (Al-Snafi 2018). This study was performed for the first time to compare the antioxidant power, phenolic and flavonoid content of Lawsonia inermis leaves and aerial parts of Haplophyllum vermiculare, in order to evaluate their capacity to improvement of oxidative stress and eventually prevention and treatment of ISD.

\section{Material and methods}

\section{Collection and extraction of the plants}

The leaves of Lawsonia inermis and aerial parts of Haplophyllum vermiculare were collected from Darab city, Fars province, Iran. The collected Seaweed species were confirmed by experts of Fasa Medicinal Plants Research Center. The voucher numbers of FMPRC-100-20 and FMPRC-100-24 Was assigned for Lawsonia inermis and Haplophyllum vermiculare respectively in the herbarium of Fasa Medicinal Plants
Research Center, Fasa University of Medical Sciences, Iran. Extraction was done by maceration method. The powders of each plants $(100 \mathrm{~g})$ was immersed in ethanol $(70: 30 \mathrm{v} / \mathrm{v})$ and kept at room temperature and darkness for one week with continuous stirring. The Solid and insoluble particles were removed by passing the extracts on a filter paper. The excess solvent was also evaporated at $50^{\circ} \mathrm{C}$ (Movaghari Pour et al., 2018). The concentrated extract was incubated at $50^{\circ} \mathrm{C}$ for $24 \mathrm{~h}$ to dry (Hoseinzadeh 2019; Seyedalipour et al., 2016).

\section{Measurement of phenolic content of herbal extracts}

The phenolic content of Lawsonia inermis and Haplophyllum vermiculare extract was measured using the Folin-Ciocalteu (FC) method (Hoseini et al., 2019). Accordingly, $500 \mu \mathrm{l}$ of the FC reagent $(10 \% \mathrm{v} / \mathrm{v})$ was added to $100 \mu \mathrm{l}$ of each extract $(1 \mathrm{mg} / \mathrm{ml})$ and incubated for $5 \mathrm{~min}$ at room temperature and darkness. Then $400 \mu 1$ of sodium carbonate $(7.5 \% \mathrm{w} / \mathrm{v})$ was added to the sample and the resulting solution was kept at room temperature and darkness for $60 \mathrm{~min}$. Finally, absorbance of the samples was measured at $765 \mathrm{~nm}$ by Synergy HTX multi-mode reader (Amoussa et al., 2015). Gallic acid was also used as standard and the phenol content of the extracts was reported in micrograms gallic acid equivalent (GAE) per miligram of dry weight ( $\mu \mathrm{g}$ GAE/mg) (Yari et al., 2016). All measurements were done at least in duplicate.

\section{Measurement of flavonoid content of herbal extracts}

Aluminum chloride method was used to measure the flavonoid content of the extracts. Accordingly, $50 \mu 1$ of the aluminum chloride $(10 \% \mathrm{w} / \mathrm{v})$ and $50 \mu 1$ of the sodium nitrite $(10 \% \mathrm{w} / \mathrm{v})$ were added to $200 \mu \mathrm{l}$ of each extract $(1 \mathrm{mg} / \mathrm{ml})$. The solution was incubated $6 \mathrm{~min}$ at room temperature and darkness, then $700 \mu 1$ of sodium hydroxide $(4 \% \mathrm{w} / \mathrm{v})$ was added and the total volume of the solution was $1 \mathrm{ml}$. After complete stirring, the resulting solution was again incubated at room temperature and darkness for $15 \mathrm{~min}$ and the absorbance of the solution was read at $510 \mathrm{~nm}$ using a Synergy HTX multimode reader. Quercetin was also used as standard and the flavonoid content of the extracts was reported in micrograms quercetin equivalent $(\mathrm{QE})$ per miligram of dry weight ( $\mu \mathrm{g} \mathrm{QE} / \mathrm{mg}$ ) (Al-Sowayan and Mousa 2014; Ayyobi et al., 2017). All measurements were done at least in duplicate. 


\section{Evaluation of antioxidant activity}

In the present study, ferric reducing antioxidant power (FRAP) and 2,2-diphenyl-1-picrylhydrazyl (DPPH) methods were used to compare the antioxidant power of Lawsonia inermis and Haplophyllum vermiculare. The FRAP assay was used to investigate the potency of monovalent antioxidants that capable of reducing $\mathrm{Fe}^{3+}$ to $\mathrm{Fe}^{2+}$ ions. Whereas in the DPPH method, the total radical scavenging activity is determined with reducing the stable nitrogen radical (DPPH radical) (Legault et al., 2011; Valverde Malaver et al., 2015).

\section{Evaluation of the monovalent reducing power}

As mentioned, the FRAP assay measures the antioxidant capacity of the extracts by reducing the $\mathrm{Fe}^{3+}$ ions (present in the Fe-TPTZ complex) to $\mathrm{Fe}^{2+}$ ions, so it's called monovalent reduction (Gallego et al., 2013). Working solution of FRAP assay is not stable and is recommended to be prepared just before testing. Therefore, the following solutions $(\mathrm{A}, \mathrm{B}, \mathrm{C})$ are mixed at a ratio of $1-1-10$, respectively. A: $10 \mathrm{mM}$ TPTZ solution in $40 \mathrm{mM}$ hydrochloric acid; $\mathrm{B}: \mathrm{FeCl} 3$ solution $(20 \mathrm{mM})$ and $\mathrm{C}$ : acetate buffer $(300 \mathrm{mM}, \mathrm{pH}=3.6)$.

In the following, $1.5 \mathrm{ml}$ of the prepared FRAP working solution was poured into a test tube and $50 \mathrm{ml}$ of herbal extracts $(1 \mathrm{mg} / \mathrm{ml})$ were added and mixed. After $10 \mathrm{~min}$ incubation at $37^{\circ} \mathrm{C}$, the absorbance of the colored solution was read at $593 \mathrm{~nm}$. Serial dilution of $\mathrm{FeSO}_{4}$ solution $(1 \mathrm{mM})$ was used as standard and the antioxidant power of the extract was reported in $\mu \mathrm{molFe}{ }^{2+} / g$ (Wang et al., 2016). All measurements were done at least in duplicate.

\section{Determination of radical scavenging activity}

Total radical scavenging activity of the extracts is determined by DPPH assay. The DPPH radicals has a purple color that turns to yellow after reduction by antioxidants in the herbal extracts. The intensity of colorlessness indicates the antioxidant power in different concentration (Carvalho et al., 2011; Wang et al., 2016). Accordingly, serial dilution of plant extracts $(10,50$, $100,200,500$ and 1000) was prepared using ethanol $70 \%$. In the following $40 \mu 1$ of herbal extracts was added to $160 \mu \mathrm{l}$ of $0.3 \mathrm{mM} \mathrm{DPPH}$ and kept at room temperature and darkness for 30min (López et al., 2011). Finally, the optical absorption changes of the samples were determined at $517 \mathrm{~nm}$ using Synergy HTX multi-mode reader. All measurements were done at least in duplicate. Ascorbic acid as a reference antioxidant was used for comparing the results. The antioxidant activity was calculated as percentage of inhibition relative to the control using the following equation:

Antioxidant power $=[$ (optical absorption of control group- optical absorption of experimental group)/ optical absorption of control group ] $\times 100$

\section{Statistic analysis}

Data were expressed as the mean $\pm \mathrm{SD}$ and compared between experimental groups using t-test and one-way analysis of variance(ANOVA). The IC50 also calculated by Four Parametric Logestic Regression. Significant difference was determined at the level of $P<0.05$. All analyses were performed using GraphPad Prism 8.0.2 (Chen et al., 2013).

\section{Results}

Phenolic and flavonoid content of the extracts

The phenolic content of the extracts was calculated by FC method based on the standard line equation of gallic acid $\left(y=219.33 x-19.727, R^{2}=0.9971\right)$. Accord-

TABLE 1: Antioxidant activity, phenolic and flavonoid content of Lawsonia inermis and Haplophyllum vermiculare extracts.

\begin{tabular}{ccccc} 
& $\begin{array}{c}\text { Phenol content } \\
(\mu \mathrm{g} \mathrm{GAE} / \mathrm{mg})\end{array}$ & $\begin{array}{c}\text { Flavonoid con- } \\
\text { tent }(\mu \mathrm{g} \mathrm{QE} / \mathrm{mg})\end{array}$ & $\begin{array}{c}\text { FRAP assay } \\
\left(\mu \mathrm{molFe}^{2+} / \mathrm{g}\right)\end{array}$ & $\begin{array}{c}\text { DPPH IC50 } \\
(\mu \mathrm{g} / \mathrm{ml})\end{array}$ \\
\cline { 3 - 4 } Lawsonia inermis & & 197.69 & 862.8932 .23 & 796.83 \\
Haplophyllum vermiculare & 76.33 & 153.20 & 765.52 & 1621 \\
$P$-value & 0.0008 & $<0.0001$ & 0.0043 & -
\end{tabular}

Data are expressed as mean \pm SD. Statistical difference between the groups was investigated by t-test and $P$-value $<0.05$ was considered as significant. 
TABLE 2: Total radical scavenging activity (\%) of different concentrations of Lawsonia inermis leaf, aerial parts of Haplophyllum vermiculare and ascorbic acid.

\begin{tabular}{|c|c|c|c|c|c|c|c|}
\hline \multirow{2}{*}{$\begin{array}{l}\text { Concentration } \\
\qquad(\mu \mathrm{g} / \mathrm{ml})\end{array}$} & \multicolumn{2}{|c|}{ Lawsonia inermis } & \multicolumn{2}{|c|}{$\begin{array}{l}\text { Haplophyllum vermic- } \\
\text { ulare }\end{array}$} & \multirow{2}{*}{ P-value } & \multicolumn{2}{|c|}{ Ascorbic acid } \\
\hline & Mean & IC50 & Mean & IC50 & & Mean & IC50 \\
\hline 10 & 1.62 & \multirow{6}{*}{671.6} & 1.28 & \multirow{6}{*}{1621} & 0.7056 & $1.83 \pm 15.79$ & \multirow{6}{*}{30.99} \\
\hline 50 & 5.49 & & 2.29 & & 0.3654 & $4.12 \pm 63.12$ & \\
\hline 100 & 8.72 & & 4.97 & & 0.0199 & $4.68 \pm 84.10$ & \\
\hline 200 & 14.03 & & 8.25 & & 0.0003 & $0.03 \pm 92.42$ & \\
\hline 500 & 36.50 & & 21.03 & & 0.0001 & $0.05 \pm 92.62$ & \\
\hline 1000 & 65.72 & & 36.32 .52 & & $0.0001>$ & $0.40 \pm 93.09$ & \\
\hline
\end{tabular}

Data are expressed as mean $\pm \mathrm{SD}$. The P-value column indicate statistical differences between Lawsonia inermis and Haplophylum vermiculare by t-test analysis. The P-value $<0.05$ was considered as significant.
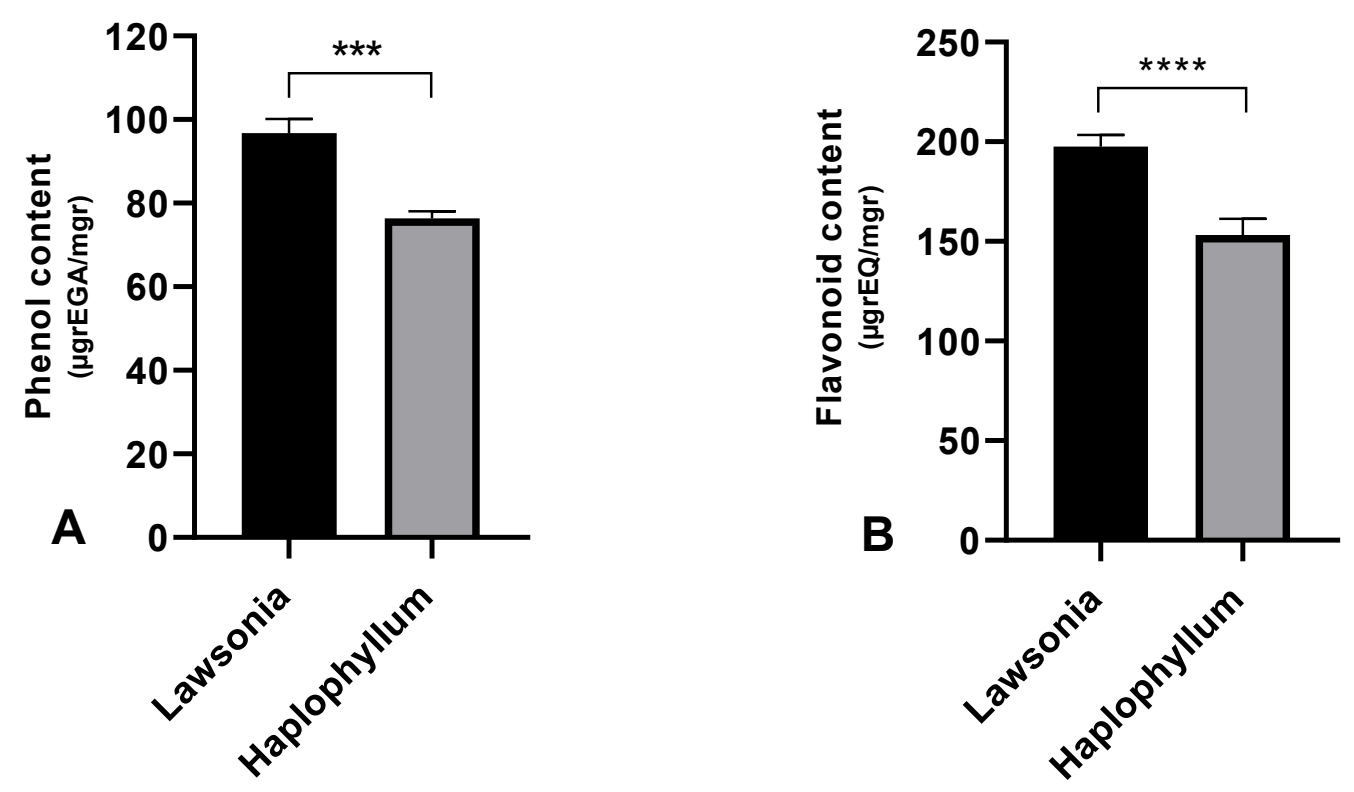

FIGURE 1. Phenolic (A) and flavonoid (B) content of hydro-ethanolic extract of Lawsonia inermis leaf and aerial parts of Haplophyllum vermiculare. Data are expressed as mean $\pm \mathrm{SD}$. Statistical difference between the groups was investigated by t-test and $P$-value $<0.05$ was considered significant. The bullet of $(* * *)$ means $P<0.001$ and the bullet of $(* * * *)$ means $P<0.0001$.

ingly, the phenolic content of hydro-ethanolic extract of henna leaf extract was $96.76 \pm 3.34 \mu \mathrm{g} \mathrm{GAE} / \mathrm{mg}$, which was significantly $(P=0.0008$, Fig. 1$)$ higher than the phenolic content of hydro-ethanolic extract of Haplophyllum vermiculare $(76.33 \pm 1.68 \mu \mathrm{g} \mathrm{GAE} / \mathrm{mg})$. The flavonoid content of the extracts was also calculated by the aluminum chloride method based on the standard line equation of quercetin $(y=415.98 x-7916.2, R 2=0.9869)$. Accordingly, the flavonoid content of hydroalcoholic extract of henna leaf extract was $197.69 \pm 5.76 \mu \mathrm{g}$ QE/ mg which was significantly $(P<0.0001$, Fig. 1$)$ higher than the flavonoid content of Haplophyllum vermiculare $(153.20 \pm 8.16 \mu \mathrm{g} \mathrm{QE} / \mathrm{mg})$.

\section{Monovalent reducing power}

The reducing power of the extracts was calculated using the FRAP assay based on the FeSO4 standard line equation $\left(y=2298.3 x-387.19, \mathrm{R}^{2}=0.9973\right)$. According to Table 1 and Figure 2, the antioxidant activity of hydroethanolic extract of Lawsonia inermis leaf was $862.89 \pm 32.23 \mu \mathrm{mol} \mathrm{Fe}{ }^{2+} / \mathrm{g}$, significantly ( $P=0.0043$ ) higher than Haplophyllum vermiculare extract $\left(765.52 \pm 29.39 \mu \mathrm{mol} \mathrm{Fe}{ }^{2+} / \mathrm{g}\right)$.

\section{Total radical scavenging activity}

The radical scavenging activity of the extracts was determined by DPPH assay. The highest radical scavenging activity of the extracts was related to ascorbic acid (IC50 $=30.99)$, Lawsonia inermis extract $($ IC50 $=671.6)$ and Haplophyllum vermiculare extract (IC50=1621), 


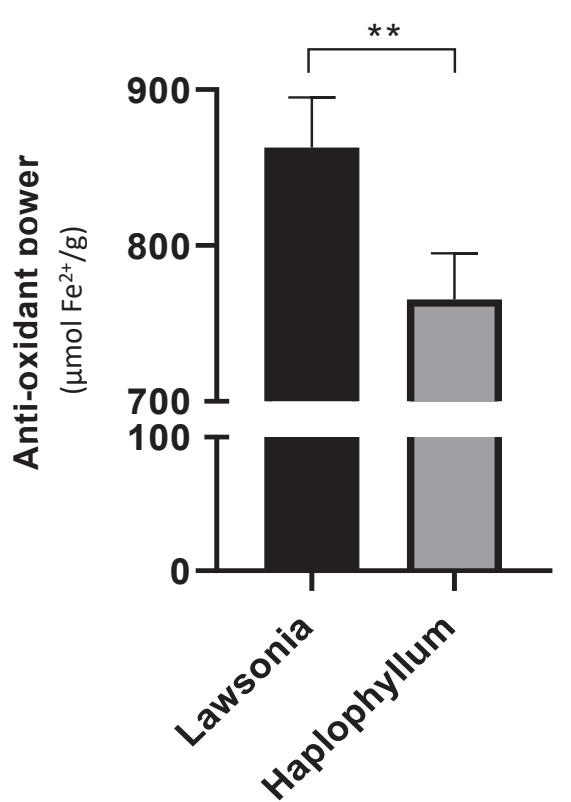

FIGURE 2. Monovalent reducing power of hydro-ethanolic extract of Lawsonia inermis leaf and aerial parts of Haplophyllum vermiculare. Data are expressed as mean \pm SD. Statistical difference between the groups was investigated by t-test and $P$-value $<0.05$ was considered significant. The bullet of $(* *)$ means $P<0.01$ in comparison of groups.

- Ascorbic Acid

- Lawsonia inermis

- Haplophyllum vermiculare

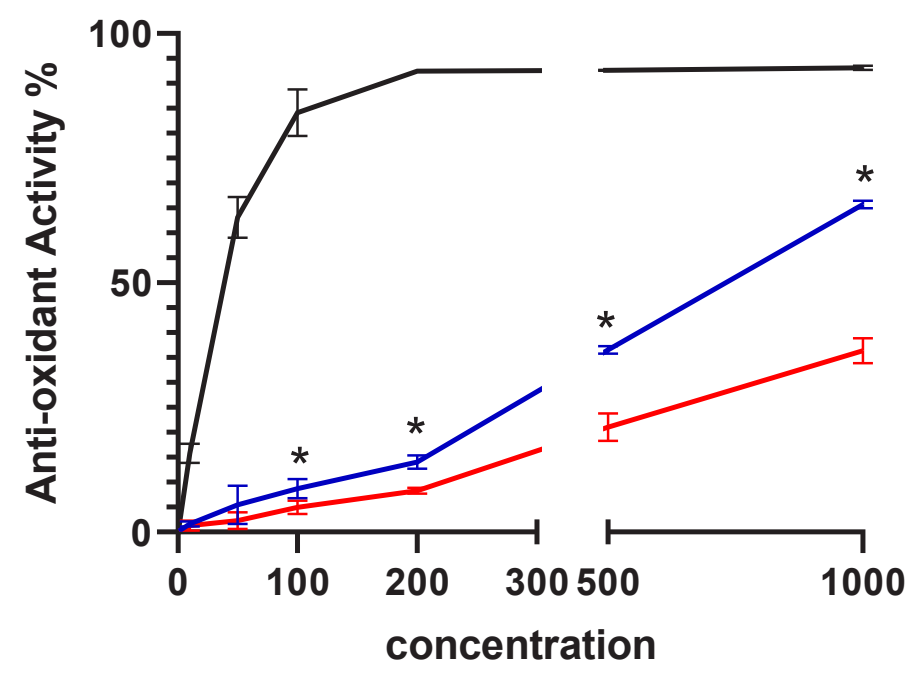

FIGURE 3. Total radical scavenging activity of hydro-ethanolic extract of Lawsonia inermis leaf, aerial parts of Haplophyllum vermiculare and Ascorbic Acid. Data are expressed as mean \pm SD and analyzed by t-test. The P-value $<0.05$ was also considered as significant. The bullet $(*)$ Indicates a statistically significant difference between Lawsonia inermis and Haplophyllum vermiculare by t-test as P-value $<0.05$.

respectively.

According to Table 2, the antioxidant activity of Lawsonia inermis extract at concentrations of 10 and $50 \mu \mathrm{g} /$ $\mathrm{ml}$ had no significant difference with Haplophyllum vermiculare. But at concentrations of 100, 200, 500 and 1000 there was a significant statistical difference between Lawsonia inermis and Haplophyllum vermiculare extracts (Table 2). There was a direct relationship between the concentration of the extracts and their antioxidant activity (Karimi et al., 2010). The antioxidant activity of Lawsonia inermis and Haplophyllum vermiculare extracts at $1000 \mu \mathrm{g} / \mathrm{ml}$ compared to $10 \mu \mathrm{g} / \mathrm{ml}$ increased by $64.1 \%$ and $35.06 \%$, respectively. 


\section{Discussion}

Biological drugs have developed with increasing knowledge of the pathogenic mechanisms and inflammatory pathways in ISD. These drugs affect the specific and functional components of the immune system and have revolutionized in treatment of inflammatory diseases at first; however currently they are restricted. Therefore, the identification and production of alternative drugs has become critical (Goldenberg 2015). Numerous papers have shown the role of oxidative stress in the pathogenesis of ISD (Kalkan et al., 2014; Zhou et al., 2009). It is appeared that improving oxidative stress is a suitable therapeutic target in these diseases (Kaur et al., 2016).

The present study showed that the antioxidant activity, phenolic and flavonoid content of the Lawsonia inermis extract were significantly higher than Haplophyllum vermiculare. The higher antioxidant activity of the Lawsonia inermis extract was double confirmed by DPPH and FRAP assay, and indicated that Lawsonia inermis contains higher radical scavenging activity and reducing power. Lawsonia inermis extract on concentration of $1000 \mu \mathrm{g} / \mathrm{ml}$ scavenged approximately $65 \%$ of the DPPH radicals and indicated more reducing power compared to Haplophyllum vermiculare. The high antioxidant potency of Lawsonia inermis leaves is probably due to its rich phenolic and flavonoid content (Mirzaei et al., 2010) and thus appears to be more effective in ISD prevention or treatment.

Multiple previous studies indicate high antioxidant activity of Lawsonia inermis (Al-Snafi 2019). For example Hasan et al. (2016) was reported the high DPPH radical scavenging activity of Lawsonia inermis by $79.16 \pm 0.98 \%$. The antioxidant activity of petroleum ether fraction of Lawsonia inermis was comparable to that of ascorbic acid (78.07.3 $\pm 1.2 \%)$. Hanachi et al. (2018) also showed that the aqueous extract of Lawsonia inermis flowers had high reducing power by FRAP assay. This high antioxidant power resulted in inhibition of gastric cancer cells (AGS line) and fibroblast cells proliferation. Rahmat et al. (2006) reported that essential oil of Lawsonia inermis showed high antioxidant effects by FTC and TBA assay that inhibited high proliferation of CaCo2, HepG2, MCF7 and MDA-MB-231 cancer cell lines. Therefore, Lawsonia inermis is likely to be effective in improving oxidative stress and suppressing proliferation of keratinocytes in ISD, especially psoriasis.

As it mentioned, Haplophyllum vermiculare probably is less effective in ISD prevention and treatment compared to Lawsonia inermis. The present study for the first time investigated the scavenging activity, reducing power and phenolic and flavonoid content of Haplophyllum vermiculare. Haplophyllum vermiculare on concentration of $1000 \mu \mathrm{g} / \mathrm{ml}$ scavenged about $36 \%$ of DPPH radicals. The reducing power of Haplophyllum vermiculare was also lower than Lawsonia inermis by $12.71 \%$ (consistent with phenolic and flavonoid content). Therefore, this plant is likely to be effective in inhibiting hypersensitivity reactions following by snake and scorpion stings, rather than improving antioxidant system. Of course, numerous studies need to be done to reach a conclusion.

As the best of our knowledge, no study has been performed on the Haplophyllum vermiculare. But some study indicated antioxidant activity of another species of Haplophyllum genus. For example in the study of Eissa et al. (2014a) the high antioxidant and cytoprotective effects of Haplophyllum tuberculatum aerial parts was indicated by employing $\mathrm{H}_{2} \mathrm{O}_{2}$ as oxidant inductor and the human astrocytoma U373-MG cell line as the cell model. The essential oils of Haplophyllum tuberculatum also showed inhibited ROS production and high scavenging activity (Eissa et al., 2014b).

Multiple studies have confirmed the efficacy of herbal antioxidants in the treatment of ISD. For example in a study, Antiga et al. (2015) showed that an antioxidant component of cinnamon (curcumin) can be effective as an complementary therapy in the treatment of psoriasis. In this study, oral administration of curcumin and topical administration of steroids compared with steroids alone had better effects on the psoriasis area severity index (PASI) reducing (Antiga et al., 2015; Hatcher et al., 2008). Mustard seed was another plant with high antioxidant activity that has been studied. In an animal study, oral administration of mustard seed has been shown to decrease the plasma malondialdehyde levels, infiltration and recruitment of $\mathrm{T}$ lymphocytes, dendritic cells and macrophages in the lesions as well as inflammatory cytokines. Oral administration of mustard seed also increased the activity of superoxide dismutase, catalase and glutathione peroxidase (Yang et al., 2013). The therapeutic effect of an antioxidant alga, Dunaliella bardawil, on psoriasis was also demonstrated in the study of 
Greenberger et al. (2012). In that study, oral consumption of the the algae resulted in a significant reduction of PASI in patients with psoriasis compared with placebo group.

The use of antioxidant effects in the treatment of ISD is not limited to herbal compounds. Some chemicals with antioxidant activity have shown similar therapeutic effects. For example, dimethylfumarate (antioxidant drug) significantly reduced proliferation, epidermal thickness and keratinocyte differentiation and reduced PASI by $55 \%$, as well as decreased inflammatory cell recruitment and infiltration in patients with psoriasis (Bovenschen et al., 2010). Utas et al. (2002) also reported that administration of propylthiouracil in patients with chronic psoriasis leads to a significant reduction of PASI by modifying the antioxidant system. In fact, propylthiouracil showed its effects by reducing malondialdehyde, inhibiting the production of ROS, increasing superoxide dismutase and glutathione peroxidase in plasma, erythrocytes and skin. Therefore, improving antioxidant activity is a suitable approach in ISD treatment and Lawsonia inermis probably is more effective in prevention and treatment of ISD compared to Haplophyllum vermiculare.

\section{Conclusion}

Development of oxidative stress and weakening of the antioxidant activity is one of the mechanisms involved in incidence and exacerbation of ISD. The native Lawsonia inermis leaf of Fars province compared to Haplophyllum vermiculare extract may be an appropriate option in the treatment of ISD (Lin and Huang 2016); therefore, it is suggested that the therapeutic effect of Lawsonia inermis leaves on different arms of the antioxidant system should be investigated in animal studies or future clinical trials. Haplophyllum vermiculare is also likely to be effective in improving hypersensitivity reactions and further studies are needed.

\section{Acknowledgment}

This work was supported by the Project fund (95154) from the Research deputy of Fasa University of Medical Sciences, Fasa, Iran. The researchers thankful Mrs Bordbar and Dadvari for kindly helping.

\section{Conflict of interest}

The authors declare that they have no known com- peting financial interests or personal relationships that could have appeared to influence the work reported in this paper.

\section{References}

Al-Snafi AE. Pharmacological importance of Haplophyllum species grown in Iraq-A review. IOSR J Pharm 2018; 8: 54-62.

Al-Snafi AE. A review on Lawsonia inermis: a potential medicinal plant. Int J Curr Pharm Res 2019; 11: 1-13. https:// doi.org/10.22159/ijcpr.2019v11i5.35695

Al-Sowayan NS, Mousa HM. Ameliorative effect of olive leaf extract on carbon tetrachloride-induced nephrotoxicity in rats. Life Sci J 2014; 11: 238-42.

Amoussa AM, Sanni A, Lagnika L. Antioxidant activity and total phenolic, flavonoid and flavonol contents of the bark extracts of Acacia ataxacantha. J Pharmacogn Phytochem 2015; 4 .

Antiga E, Bonciolini V, Volpi W, Del Bianco E, Caproni M. Oral curcumin (Meriva) is effective as an adjuvant treatment and is able to reduce IL-22 serum levels in patients with psoriasis vulgaris. BioMed Res Int 2015; 2015. https://doi.org/10.1155/2015/283634

Ayyobi N, Fattahi M. Induction effects of colchicine and chitosan on rosmarinic acid production in hairy root cultures of Zarrin-Giah (Dracocephalum kotschyi Boiss). J Cell Mol Res 2017; 30-1-3.

Bovenschen HJ, Langewouters AM, van de Kerkhof PC. Dimethylfumarate for psoriasis. Am J Clin Dermatol 2010; 11: 343-50. https://doi.org/10.2165/11533240000000000-00000

Carvalho IS, Cavaco T, Brodelius M. Phenolic composition and antioxidant capacity of six artemisia species. Ind Crop Prod 2011; 33: 382-8. https://doi.org/10.1016/j.indcrop.2010.11.005

Chen Z, Bertin R, Froldi G. EC50 estimation of antioxidant activity in DPPH assay using several statistical programs. Food Chem 2013; 138: 414-20. https://doi.org/10.1016/j. foodchem.2012.11.001

Eissa TF, González-Burgos E, Carretero ME, Gómez-Serranillos MP. Biological activity of HPLC-characterized ethanol extract from the aerial parts of Haplophyllum tuberculatum. Pharm Biol 2014a; 52: 151-6. https://doi.org/ 10.3109/13880209.2013.819517

Eissa TF, González-Burgos E, Carretero ME, Gómez-Serranillos MP. Compositional analysis and in vitro protective activity against oxidative stress of essential oils from 
Egyptian plants used in traditional medicine. Nat Prod Commun 2014b; 9: 1934578X1400900939. https://doi. org/10.1177/1934578X1400900939

Gallego MG, Gordon MH, Segovia FJ, Skowyra M, Almajano MP. Antioxidant properties of three aromatic herbs (rosemary, thyme and lavender) in oil-in-water emulsions. J Am Oil Chem Soc 2013; 90: 1559-68. https://doi. org/10.1007/s11746-013-2303-3

Goldenberg G. New systemic therapies for psoriasis. Cutis 2015; 95: 155-60.

Greenberger S, Harats D, Salameh F, Lubish T, Harari A, Trau H, et al. 9-cis-Rich $\beta$-Carotene powder of the Alga Dunaliella reduces the severity of chronic plaque psoriasis: a randomized, double-blind, placebo-controlled clinical trial. J Am Coll Nutr 2012; 31: 320-6. https://doi.org/1 0.1080/07315724.2012.10720430

Hanachi P, Salehizadeh S, Kiarostami K, Ramezani R. Investigation of antioxidant properties of Ocimum basilicum and impatiens walleriana and their cytotoxic effect on gastric cancer AGS cell line. J Cell Tissue 2018; 9: 378-87.

Hasan KM, Yesmin S, Akhter SF, Paul S, Sarker S, Islam A, et al. Hepatoprotective potentiality of various fractions of ethanolic extracts of lawsonia inermis (henna) leaves against chemical-induced hepatitis in rats. Biochem Mol Biol 2016; 1: 17-22.

Hatcher H, Planalp R, Cho J, Torti FM, Torti SV. Curcumin: from ancient medicine to current clinical trials. Cell Mol Life Sci 2008; 65: 1631-52. https://doi.org/10.1007/ s00018-008-7452-4

Hoseini S, Rashidi L, Homapour M. Investigation of polyphenolic compounds and antioxidant properties of black peel pomegranate Juice cultivar (Punica granatum) in Saveh. Iranian J Nutr Sci Food Technol 2019; 14: 99-108.

Hoseinzadeh F. Study of antioxidant and antimicrobial properties of grape seed extract and evaluation of its sensory characteristics in sponge cake. Food Sci Technol 2019; 15: 165-78.

Kalkan G, Seçkin HY, Duygu F, Akbaş A, Özyurt H, Şahin M. Oxidative stress status in patients with acute urticaria. Cutan Ocul Toxicol 2014; 33: 109-14. https://doi.org/10.3 109/15569527.2013.808658

Karimi E, Oskoueian E, Hendra R, Jaafar HZ. Evaluation of Crocus sativus L. stigma phenolic and flavonoid compounds and its antioxidant activity. Molecules 2010; 15 : 6244-56. https://doi.org/10.3390/molecules15096244

Kaur M, Sharma S, Kukreja S, Kaur J, Bassi R. Study of oxidative stress in patients of psoriasis. Int J Res Dermatol
2016; 2: 95-98. https://doi.org/10.18203/issn.2455-4529. IntJResDermatol20164007

Legault J, Perron T, Mshvildadze V, Girard-Lalancette K, Perron S, Laprise C, et al. Antioxidant and anti-inflammatory activities of quercetin 7-O- $\beta$-D-glucopyranoside from the leaves of Brasenia schreberi. J Med Food 2011; 14: 1127-34. https://doi.org/10.1089/jmf.2010.0198

Lin X, Huang T. Oxidative stress in psoriasis and potential therapeutic use of antioxidants. Free Radic Res 2016; 50: 585-95. https://doi.org/10.3109/10715762.2016.1162301

López A, Rico M, Rivero A, de Tangil MS. The effects of solvents on the phenolic contents and antioxidant activity of Stypocaulon scoparium algae extracts. Food Chem 2011; 125: 1104-9. https://doi.org/10.1016/j.foodchem.2010.09.101

Mastanaiah J, Prabhavathi NB, Varaprasad B. Invitro antibacterial activity of leaf extracts of Lawsonia Inermis. Int J Pharmtech Res 2011; 3: 1045-9.

Mirzaei A, Akbartabar M, Sadeghi H, Sharifi B. The antioxidant activities and total phenolic of artemisia martima, achillea millefolium and matricaria recutica. Armaghane danesh 2010; 15: 243-52.

Movaghari Pour A, Sheikh Fathollahi M, Poor Zamani M, Abedini S, Jamali Z. Comparison of anti-fungal effect of Origanum vulgare extract versus nystatin on Candida albicans; an in vitro study. J Mashhad Dent Sch 2018; 42: 277-1.

Rahmat A, Edrini S, Ismail P, Hin TY, Bakar MA. Chemical constituents, antioxidant activity and cytotoxic effects of essential oil from Strobilanthes crispus and Lawsonia inermis. J Biol Sci 2006; 6: 1005-10. https://doi.org/10.3923/ jbs.2006.1005.1010

Seyedalipour B, Pourakbar E, Taravati A. The cytotoxic effect of ethanolic extract of Pistacia khinjuk leaf on HeLa and MCF-7 cancerous cell lines. J Rafsanjan Univ Med Sci 2016; 14: 939-52.

Shah AA, Sinha AA. Oxidative stress and autoimmune skin disease. Eur J Dermatol 2013; 23: 5-13. https://doi. org/10.1684/ejd.2012.1884

Sies H. Oxidative stress: a concept in redox biology and medicine. Redox biology 2015; 4: 180-3. https://doi. org/10.1016/j.redox.2015.01.002

Utaş S, Köse K, Yazici C, Akdaş A, Keleştimur F. Antioxidant potential of propylthiouracil in patients with psoriasis. Clin Biochem 2002; 35: 241-6. https://doi.org/10.1016/ S0009-9120(02)00294-1

Valverde Malaver CL, Colmenares Dulcey AJ, Isaza 
Martínez JH. Comparison of DPPH free radical scavenging, ferric reducing antioxidant power (FRAP), and total phenolic content of two meriania species (Melastomataceae). Revista de Ciencias 2015; 19: 117-24. https://doi. org/10.25100/rc.v19i2.6271

Wang B, Huang Q, Venkitasamy C, Chai H, Gao H, Cheng $\mathrm{N}$, et al. Changes in phenolic compounds and their antioxidant capacities in jujube (Ziziphus jujuba Miller) during three edible maturity stages. LWT-Food Sci Technol 2016; 66: 56-62. https://doi.org/10.1016/j.lwt.2015.10.005

Yang R, Zhou Q, Wen C, Hu J, Li H, Zhao M, et al. Mustard seed (S inapis A lba L inn) attenuates imiquimod-in- duced psoriasiform inflammation of $\mathrm{BALB} / \mathrm{c}$ mice. $\mathrm{J}$ Dermatol 2013; 40: 543-52. https://doi.org/10.1111/13468138.12119

Yar IS, Karamian R, Asadbegy M. Total phenol and flavonoid contents of Meristotropis xanthioides Vassilcz. species extract and its protective effect on ethanol-induced hepatotoxicity. J Cell Tissue 2016; 7: 323-32.

Zhou Q, Mrowietz U, Rostami-Yazdi M. Oxidative stress in the pathogenesis of psoriasis. Free Radic Biol 2009; 47: 891-905. https://doi.org/10.1016/j.freeradbiomed.2009.06.03 